\title{
The Development of Interactive Instructional Media Using Adobe Flash in a Form of Game on the Geometry Lesson (Cube and Cuboid) for Secondary School
}

\author{
Herdiansyah, Yus Mochamad Cholily, Hendarto Cahyono \\ Study Program of Mathematics Education \\ Faculty of Teacher Training and Education \\ University of Muhammadiyah Malang \\ herdy019@gmail.com
}

\begin{abstract}
The purpose of this study was developing an interactive instructional media using Adobe Flash in a form of the game at the geometry lesson (cube and cuboid) and analyzing the effectiveness of the media. The type of this study was Research and Development $(\mathrm{R} \& \mathrm{D})$. The media development was started from potential and problem phase, data collection, product design, design validation, design revision, and product trial. The instruments of the study were the questionnaire validation and the questionnaire response of teacher and students. The results showed that development of interactive instructional media using Adobe Flash in a form of the game was valid. The average score of material expert was 3.43 and the average score of media expert was 3.61. The effectiveness of the media using Adobe Flash in a form of the game was effective. It was based on the score of teacher's response was $78.57 \%$ and the score of students' response was $86.42 \%$.
\end{abstract}

Keywords: instructional media, Adobe Flash, geometry.

\section{INTRODUCTION}

Basically, education, one of which is an education in the school environment, is essential in human life. School education is designed and implemented intentionally with certain rules (Tirtarahardja \& Sulo, 2012). Certainly, education carried out in the school environment requires the role of the teacher in it. The teacher must be able to encourage the students to develop their knowledge and skill in solving the problem they face in each subject in the learning process. One of the important subjects in education are mathematics. However, mathematics is often considered boring and difficult to learn; it is because mathematics has an abstract object of study and formulas that are difficult to understand (Fitri, 2014).

According to Safrina, et al. (2014), among various branches of mathematics, geometry is the lesson which occupies the most concerning position. It shows that students experience difficulties in understanding geometry. As evidence, the result of the observation conducted by the researcher at Muhammadiyah 8 Batu Secondary School on November 4, 2017, is that students had difficulty in understanding geometry material. In this case, concretizing geometry shapes and formulas used are needed. In addition, the teacher uses textbook and blackboard only as learning media. Besides, the lecture method is used that the learning only occurs in one direction and students tend to be passive because they only listen to the teacher's explanation.

Seeing these conditions, a right understanding to support students' abilities and skills in learning geometry is needed, one of which is by using learning media. Arsyad (2011) states that the main function of learning media is as a teaching media used by teachers in delivering learning materials. 
Along with the development of information and communication technology, many types of media can be used by teachers; one of them is computer-based learning media packaged in the form of a game. The use of computers in the learning process allows students to have control over their learning activities that make them do not just listen to the teachers' explanation. Besides, using the game as a learning media makes students enjoy learning the material as they are playing the game which is an activity they like (Rohwati, 2012).

Adobe Flash is computer software that can make various kinds of objects, animations, and videos (Waxer, 2011). It has many advantages compared to other software. For instance, this software is equipped with an action script which is used to store variables and values, perform calculations, and many more. Therefore, Adobe Flash is suitable for making games, animations, interactive menus, and so on.

Based on the explanation above, the researcher is interested in developing learning media entitled "The Development of Interactive Instructional Media Using Adobe Flash in A Form of Game on The Geometry Lesson (Cube and Cuboid) for Secondary School." The objective of this study is to develop an interactive instructional media using Adobe Flash in a form of the game at the geometry lesson (cube and cuboid) and analyze the effectiveness of the media.

\section{RESEARCH METHOD}

The type of research used Research and Development (R\&D). There are six stages of the learning media development process adapted from Sugiyono (2013), namely: (1) potential and problem, (2) data collection, (3) product design, (4) design validation, (5) design revision, and (6) product trial. The subjects in this study were thirty students of Class of VIII E, Muhammadiyah 8 Batu Secondary School. The questionnaire was used as the instruments of the study to obtain data. There were four types of questionnaires used in this study: media validation, material validation, teachers' response, and the students' response questionnaire.

The data obtained was continued with data analysis which purpose to determine the validity and effectiveness of learning media that have been developed.

\section{RESULT AND DISCUSSION}

The development of interactive instructional media using Adobe Flash in a form of the game on the geometry lesson (cube and cuboid) is based on the stage of the type of research and development (R\&D) starting from potential identification and problem, data collection, product design, design validation, design revision, and product trial.

The first stage, the potential and problem found by doing the observation at Muhammadiyah 8 Batu Secondary School on November 4, 2017 was that students had difficulty in understanding abstract material. Besides, the teacher still used conventional learning method that the learning only occurs in one direction and students tend to be passive because they only listen to the teacher's explanation. In the next stage, data collection, the data obtained in the form of material and basic competencies that would be used in the media as well as several previous studies. The result of this data collection was used as materials for designing products. After the data are collected, the third stage which was product design was continued by making the material design and product display design until the product is finished. The fourth stage, design validation was carried out by material and media experts using material validation questionnaire and media validation questionnaire. In the fifth stage, the design revision was based on material expert and media expert suggestion during design validation. 
For the last stage, product trial was done when the product developed had been declared valid and had been revised according to the advice of material expert and media expert. The process of testing this product aimed to determine the teachers and students' responses to the media that had been developed.

Purwanto (2016) in his research on website media development conducted a media validity test by looking at the percentage of the final score of the validation questionnaire. In his study, the final score was $83.33 \%$ and was valid. According to Fatimah (2017), whereas, in her research on the development of CBI (Computer Based Instruction) media in the form of the game on algebraic material, the validity of media is tested by looking at the average values based on the material validation questionnaire and media validation questionnaire. From her study, the media was valid interpreted based on the assessment of material expert on 4.49 and media expert at 4.56. In line with this, interactive learning media using Adobe Flash in a form of the game was also tested for validity using material validation questionnaire and media validation questionnaire. The assessment result from material expert obtained an average total value of 3.43 while the result from media expert obtained an average total value of 3.61 . Therefore, the media is valid and suitable for use in the learning process.

The learning media that has been declared valid will be tested at school to determine the teachers and students' response to the media. In her research, Putriani (2017) stated that to identify the effectiveness of the use of aAndroid-based learning media with the Construct 2 program on geometry using students' response questionnaire and students' outcome tests as the instruments. Similarly, Umam (2015) used students' response questionnaire to see the effectiveness of the media developed on the learning media based on educational games. As the result, as much as $86.33 \%$ students' responses with very good criteria and positive responses was shown by students to the media based on comments and suggestions given by students. Hence, it could be said that the media itself was effective.

On the other hand, this study uses teachers and students' response to identify the effectiveness of learning media that has been developed. Based on the questionnaire of teachers and students' response, the presentations are $78.57 \%$ and $86.42 \%$. Therefore, according to the media effectiveness level category table, the categories are effective and very effective. In line with the result, as stated by Arikunto (2009), the learning media that is developed is effective if the students' response percentage is above $70 \%$. By the previous statement, it can be concluded that interactive learning media using Adobe Flash in the form of a game is effective and suitable for mathematics learning.

\section{CONCLUSION}

The development of interactive learning media using Adobe Flash in the form of a game was done in the six stages: potential and problem stage, data collection, product design, design validation, design revision, and product trial. The assessment result from material validation obtained an average total value of 3.43 while the result from media validation obtained an average total value of 3.61. Therefore, the developed learning media is valid. Besides, the results of media trial in school shown the score of teachers and students' response, the presentations are $78.57 \%$ and $86.42 \%$. By that result, the interactive learning media using Adobe Flash in the form of a game is effective.

The interactive learning media using Adobe Flash in the form of a game is packaged in the exe format and stored offline. Besides, this media can only be operated on a computer. Since the material used is geometry lesson (cube and cuboid) for secondary school, the researcher expects the media to be developed using different software and material in the future. 


\section{REFERENCES}

Arsyad, A. 2011. Media Pembelajaran. Jakarta: PT Raja Grafindo Presada.

Fatimah, A. S. 2017. Pengembangan Media CBI (Computer Based Instruction) Bentuk Permainan Pada Materi Operasi Aljabar. Skripsi S1. Pendidikan Matematika. Universitas Muhammadiyah Malang.

Fitri, R. 2014. Penerapan Strategi The Firing Line pada Pembelajaran Matematika Siswa Kleas XI IPS SMA Negeri 1 Batipuh. Jurnal Pendidikan Matematika. hlm 18-22.

Handayani, I. 2013. Pengembangan Media Pembelajaran Berbantuan Komputer pada Materi Diagram Venn untuk Siswa Kelas VII SMP. Jurnal Pendidikan Matematika. hlm 1-11.

Hobri. 2010. Metodologi Penelitian dan Pengembangan. Jember: Pena Salsabila.

Purwanto, S. (2016). Pengembangan Website Matematika Sekolah Untuk Meningkatkan Hasil Belajar Mahasiswa, Siswa Sekolah menengah dan Sekolah Dasar. PROSIDING, 591598.

Putriani, D. 2017. Pengembangan Media Pembelajaran Berbasis Android dengan program Construct 2 pada Materi Bangun Ruang Sisi Data untuk Siswa SMP Kelas 8. Jurnal Pendidikan Matematika. Vol 6, No 3, hlm 1-10.

Rohwati, M. 2012. Penggunaan Education Game Untuk Peningkatan Hasil Belajar IPA Biologi Konsep Klasifikasi Makhluk Hidup. Jurnal Pendidikan IPA Indonesia. Vol. 1, No. 1, hlm 75-81.

Safrina, Khusnul, dkk. 2014. Peningkatan Kemampuan Pemecahan Masalah Geometri melalui Pembelajaran Kooperatif Berbasis TeoriVan Hiele. Jurnal Didaktik Matematika. Vol. 1, No. 1, hlm 9-20.

Sugiyono. 2013. Metode Penelitian Pendidikan (Pendekatan Kuantitatif, Kualitatif, dan R\&D). Bandung: Alfabeta.

Tirtarahardja, U., \& Lulo, S. L. (2012). Pengantar Pendidikan. Jakarta: PT Rineka Cipta.

Umam, K. (2016). Media Pembelajaran Interaktif Berbasis Game Edukasi Android Menggunakan App Inventor 2 pada Materi Matematika Kelas VII. Skripsi S1. Pendidikan Matematika. Universitas Muhammadiyah Malang.

Waxer, B. M. 2011. Adobe Flash Professional CS5 Ilustrated. Boston: Course Technology. 